\title{
Forest harvesting impacts on microclimate conditions and sediment transport activities in a humid periglacial environment
}

\author{
Fumitoshi Imaizumi $^{1}$, Ryoko Nishii ${ }^{2}$, Kenichi Ueno $^{3}$, and Kousei Kurobe ${ }^{4}$ \\ ${ }^{1}$ Faculty of Agriculture, Shizuoka University, Shizuoka, 422-8529, Japan \\ ${ }^{2}$ Center for Transdisciplinary Research, Niigata University, Niigata, 950-2181, Japan \\ ${ }^{3}$ Faculty of Life and Environmental Sciences, University of Tsukuba, \\ Tsukuba, Ibaraki, 305-8572, Japan \\ ${ }^{4}$ Pacific Consultants Co., Ltd, Tokyo, 101-8462, Japan
}

Correspondence: Fumitoshi Imaizumi (imaizumi@ shizuoka.ac.jp)

Received: 9 February 2018 - Discussion started: 8 March 2018

Revised: 2 August 2018 - Accepted: 16 December 2018 - Published: 14 January 2019

\begin{abstract}
Sediment transport activities in periglacial environments are controlled by microclimate conditions (i.e., air and ground temperatures, throughfall), which are highly affected by vegetation cover. Thus, there is the possibility that forest harvesting, the most dramatic change to vegetation cover in mountain areas, may severely impact sediment transport activities in periglacial areas (i.e., soil creep, dry ravel). In this study, we investigated changes in sediment transport activities following forest harvesting in steep artificial forests located in a humid periglacial area of the southern Japanese Alps. In the southern Japanese Alps, rainfall is abundant in summer and autumn, and winter air temperatures frequently rise above and fall below $0^{\circ}$. Our monitoring by time lapse cameras revealed that gravitational transport processes (e.g., frost creep and dry ravel) dominate during the freeze-thaw season, while rainfall-induced processes (surface erosion and soil creep) occur during heavy rainfall seasons. Canopy removal by forest harvesting increased the winter diurnal ground surface temperature range from 2.7 to $15.9^{\circ} \mathrm{C}$. Forest harvesting also increased the diurnal range of net radiation and ground temperature, and decreased the duration of snow cover. Such changes in the microclimate conditions altered the type of winter soil creep from frost creep to diurnal needle-ice creep. Winter creep velocity of ground surface sediment in the harvested site ( $>2 \mathrm{~mm} \mathrm{day}^{-1}$ on the days with frost heave) was significantly higher than that in the non-harvested site (generally $<1 \mathrm{~mm}$ day $^{-1}$ ). Meanwhile, sediment flux on the hillslopes, as observed by sediment traps, decreased in the harvested
\end{abstract}

site. Branches of harvested trees left on the hillslopes captured sediment moving downslope. In addition, the growth of understories after harvesting possibly reduced surface erosion. Consequently, removal of the forest canopy by forest harvesting directly impacts the microclimate conditions (i.e., diurnal range of ground temperature and net radiation, duration of snow cover) and increases frequency and velocity of periglacial soil creep, while sediment flux on hillslopes is decreased by branches left on the hillslopes and recovery of understories. The impact of forest harvesting on sediment transport activity is seasonally variable in humid periglacial areas, because microclimate conditions relevant to both freezethaw processes and precipitation-induced processes control sediment transport.

\section{Introduction}

Sediment transport activities in the periglacial environment are controlled by a hillslope's microclimate conditions (i.e., air and ground temperatures, throughfall), which are highly affected by vegetation cover (Matsuoka, 2001; Boelhouwers et al., 2000; Harris et al., 2008b; Ueno et al., 2015). Thus, there is the possibility that forest harvesting, the most dramatic change to vegetation cover in mountain areas (Imaizumi and Sidle, 2012; Goetz et al., 2015), may severely impact sediment transport activities in periglacial areas (i.e., soil creep, dry ravel). Knowledge of the effects of forest har- 
vesting on sediment transport activities is needed to develop better mitigation measures for preventing sediment disasters.

Previous studies emphasized that vegetation cover, especially a forest canopy, controls microclimate conditions on mountain hillslopes. Tree crowns intercept precipitation (Xiao et al., 2000; Fan et al., 2014) and also control net radiation and ground surface temperature (Ueno et al., 2010, 2015). Sediment transport triggers, such as changes in soil moisture, generation of overland flow, and freeze-thaw of groundwater, are affected by these microclimate conditions (Wainwright et al., 2000; Gray et al., 2002; Ueno et al., 2015). Therefore, removal of the canopy by forest harvesting alters sediment transport opportunities via changes to the microclimate conditions.

Sediment transport activity is also controlled physically by forest components (e.g., understory, tree roots, and woody debris). The understory reduces kinetic energy of raindrops that splash soil particles, reducing surface erosion (Fukuyama et al., 2010; Nanko et al., 2015). Tree roots reinforce slope stability, reducing the frequency of shallow landslides and debris flows (Imaizumi et al., 2008; Goetz et al., 2015). Woody debris captures sediment traveling on hillslopes (Hartanto et al., 2003; Imaizumi et al., 2017). Because forest harvesting dramatically changes these components, sediment transport likely changes after forest harvesting.

Mountain hillslopes are generally formed by a combination of various types of sediment transport processes (Roberts and Church, 1986; Benda, 1990; Imaizumi et al., 2017). However, the majority of studies on the relationship between vegetation condition and sediment transport activities have focused on a single sediment transport process (Miyata et al., 2009; Borrelli et al., 2015; Goetz et al., 2015). Sediment transport processes triggered by rainfall, such as surface erosion and landslides, are active in areas with abundant rainfall (Miyata et al., 2009; Fiorucci et al., 2011), while those triggered by freeze-thaw are active in cold environments (Matsuoka, 2001; Boelhouwers et al., 2000, 2003; Harris et al., 2008b). In humid periglacial areas, both rainfall and freeze-thaw activities highly affect sediment transport processes (Imaizumi et al., 2015, 2017). Therefore, the effect of forest harvesting on sediment transport activities possibly changes seasonally, depending on the trigger mechanism and the predominant type of sediment transport.

The southern Japanese Alps are characterized as being a humid periglacial area because of abundant annual precipitation $(>2500 \mathrm{~mm})$ and frequent winter freeze-thaw cycles, especially in mid-elevation mountain ranges (e.g., 1000 to $2000 \mathrm{~m}$ ) (Imaizumi et al., 2006, 2017). Gravitational sediment transport processes (e.g., soil creep and dry ravel), which have been poorly studied in relation to vegetation change, are more important sediment transport processes than surface wash because of the steep terrain (Imaizumi et al., 2017). Over $80 \%$ of the southern Japanese Alps consist of cold temperate natural forests and conifer artificial forests.
Social demand for forest harvesting has been increasing in Japan as artificial forests, which were vigorously replanted in 1960 and 1970, have matured and become a recyclable and domestically producible resource. Ueno et al. (2015) showed that the type of winter solifluction changes from frost creep to needle-ice creep following forest harvesting in the southern Japanese Alps, because of changes in the net radiation and ground temperature. However, their interpretation of the sediment transport process is limited to winter frost heave and solifluction on a micro scale (e.g., $<1 \mathrm{~m}^{2}$ ). Post-harvesting sediment transport processes during heavy rainfall events (generally from June to October), which are also an important climatic characteristic in this area (Imaizumi et al., 2006, 2017), should be assessed to evaluate the overall impact of forest management. Additionally, the effect of changes in the ground surface conditions after forest harvesting (e.g., residual branches of harvested trees, growth of understories) on sediment transport processes has not been understood sufficiently.

The aim of this study is to clarify the impacts of forest harvesting on microclimate conditions and sediment transport processes throughout the year in a humid periglacial area. We studied seasonal changes in the impact of forest harvesting on microclimate conditions (i.e., radiation, ground temperature, throughfall, freeze-thaw of groundwater) and sediment transport (i.e., soil creep, dry ravel, surface erosion) by intensive and comprehensive monitoring of harvested and non-harvested forests in the southern Japanese Alps.

\section{Study site}

The study site was set in Ikawa University Forest, University of Tsukuba, located on the southern side of the southern Japanese Alps, central Japan (Fig. 1). The geology consists of alternating sandstone and shale layers covered by brown forest soil and podzol. Annual precipitation is high (an annual average of $2800 \mathrm{~mm}$ from 1993 to 2002; Imaizumi et al., 2010) because the area lies in the East Asia Summer Monsoon region. Heavy rainfall events (daily rainfall $>100 \mathrm{~mm} \mathrm{day}^{-1}$ ) mainly occur in the summer months (June to October) due to the activities of the Baiyu front and typhoons. Radiative cooling in the morning is significant in winter, as skies are clear for long periods (Ueno et al., 2015). Winter snowfall occurs sporadically in high-elevation areas from December to March due to passing extratropical cyclones that account for about $15 \%$ of the total annual precipitation, but plays an important role in changing the ground surface condition via snow cover (Ueno et al., 2015). Surface air temperatures frequently rise above and fall below $0^{\circ}$ during the winter, even at around $1200 \mathrm{~m}$ a.s.l. (Ueno et al., 2015; Imaizumi et al., 2017).

The study site was $1.5 \mathrm{ha}$ and faced west at 1180 $1310 \mathrm{~m}$ a.s.l. in Ikawa University Forest (Fig. 1). Japanese cypress (evergreen needle leaf) trees were planted over the 

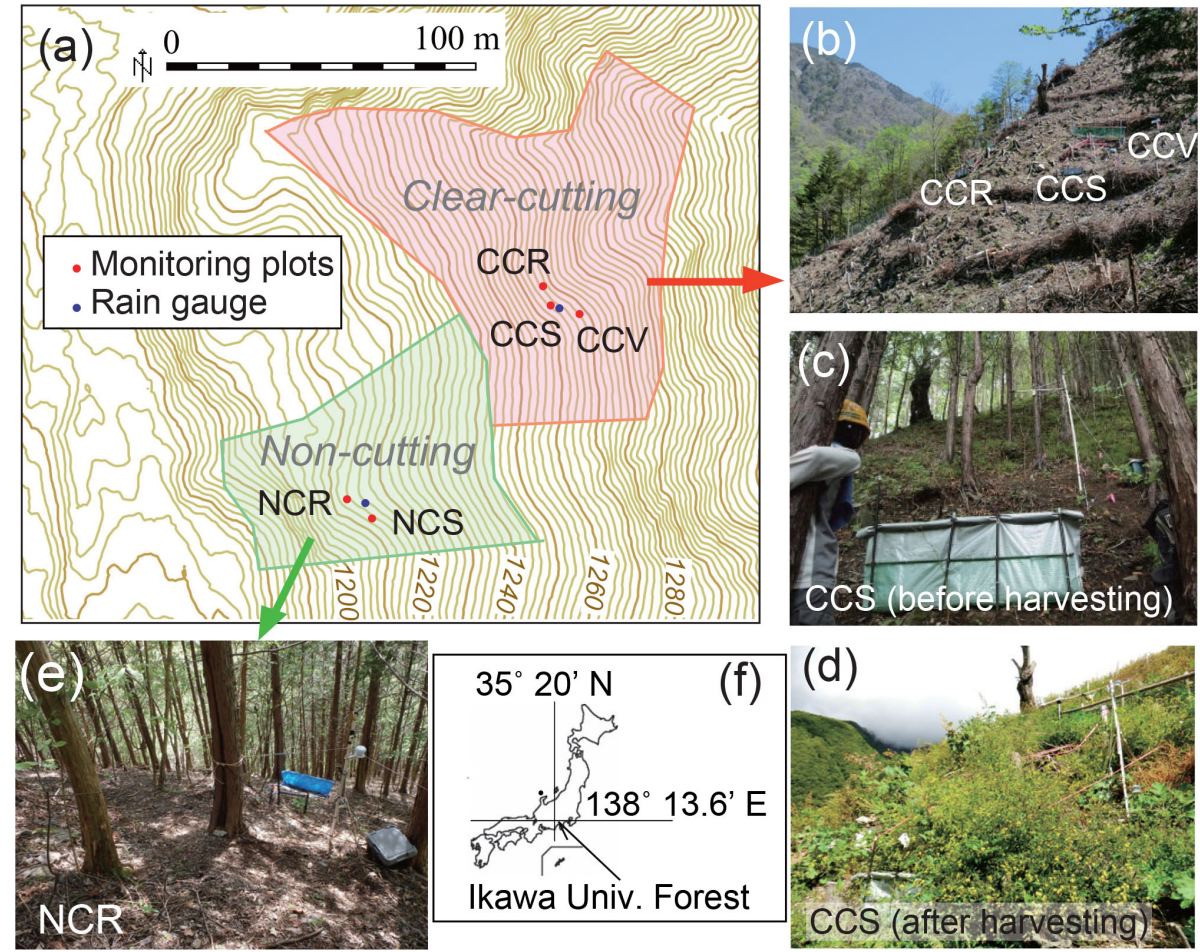

Figure 1. Topographic map and photographs showing observation sites in Ikawa University Forest. (a) Topographic map of the study site. (b) Photograph of site CC after forest harvesting (13 May 2013). Branches of harvested trees were piled up in lines parallel to the contour lines. (c) Photograph of plot CCS before forest harvesting (26 August 2011). The synthetic sheet at the lower end is the sediment trap. A radiometer was attached to the horizontal metal pipe extending from a white vertical pole on the right side of the image. (d) Photograph of plot CCS after forest harvesting (26 September 2013), taken from the same location as Fig. 1c. (e) Photograph of plot NCR (14 May 2015). (f) Location of Ikawa University Forest within Japan.

study site in 1975. Annual herbaceous plants (e.g., Leucosceptrum and fern) covered 0 to $20 \%$ of the ground surface before forest harvesting (Fig. 1c). A 0.87 ha area in the upper part of the study area, called the clear-cut (CC) site in this study, was harvested during March-September 2012 (Ueno et al., 2015). Logging was conducted by skyline yarding to avoid damaging the slope surface by dragging logs. After clear-cutting, branches of harvested trees were piled up in lines parallel to the contour lines with spacings of 5 to $10 \mathrm{~m}$ (Fig. 1b). This work aimed to prepare the environment for revegetation and is common in Japan. After clear-cutting, Japanese cypress trees were replanted in spring 2013. Herbaceous plants (e.g., Japanese knotweed, artemisia, brambles, and thistle) covered more than $90 \%$ of the ground by July 2013 (Fig. 1d). No forest management was conducted in the lower part of the study site, which is called the noncutting (NC) site. We tried to select a control site, NC, with as similar tree and topographic conditions as possible; however, the slope gradient at site $\mathrm{CC}\left(35-45^{\circ}\right)$ was slightly greater than that at site $\mathrm{NC}\left(30-40^{\circ}\right.$, Table 1$)$.

We set up three monitoring plots corresponding to the small-scale topography in the CC site (CCR, CCS, and CCV at ridge, straight, and valley-shaped cross-sectional topogra-
Table 1. Setting of monitoring plots.

\begin{tabular}{llrr}
\hline Plot & $\begin{array}{l}\text { Cross-sectional } \\
\text { topography }\end{array}$ & $\begin{array}{r}\text { Slope gradient* } \\
\text { (degree) }\end{array}$ & $\begin{array}{r}\text { Contributing } \\
\text { area }\left(\mathrm{m}^{2}\right)\end{array}$ \\
\hline CCR & ridge & 43 & 7 \\
CCS & straight & 43 & 28 \\
CCV & valley & 40 & 70 \\
NCR & ridge & 34 & 6 \\
NCS & straight & 38 & 40 \\
\hline
\end{tabular}

* Slope gradient measured $10 \mathrm{~m}$ upslope from sediment traps.

phies, respectively) and two monitoring plots in the NC site (NCR and NCS at ridge and straight-shaped cross-sectional topographies, respectively (Fig. 1, Table 1). The contributing areas of plots at ridge-shaped slopes (CCR and NCR) were smallest in size, while the valley-shaped slope (CCV) was the largest in size. Grain size at plot CCV was clearly larger than at the other plots due to the accumulation of boulders transported as rockfall and dry ravel from the upper slopes (Fig. 2). 


\section{Methodology}

\subsection{Microclimate and freezing-thawing condition}

Preliminary observations of the microclimate, including throughfall and ground surface temperature, were carried out in both the CC and NC sites in the period June 2011 to March 2012, before forest harvesting (periods 1 to 11 in Table 2). During the harvesting period (periods 12 to 14 ), observations were continued in site $\mathrm{NC}$ and suspended in site CC. After forest harvesting, intensive monitoring of radiation budget, snow depth, and ground temperature was conducted in the periods 28 January to 27 May 2013 and 2 December 2013 to 24 March 2014 in both sites (Tables 2, 3).

Rainfall at both sites (CC and NC) was observed using tipping bucket rain gauges $(0.2 \mathrm{~mm}$ for one tip) without a heating system. Rainfall monitoring in site $\mathrm{NC}$ was suspended for several months due to troubles with the monitoring system (bad electrical connections, choking of the rain gauge by leaf fall, troubles with the data logger) in the summers of 2013 and 2014. In addition, there were some other short intermissions (duration of $<1$ month) in both sites due to mechanical troubles. In this study, rainfall data for both sites for the periods without monitoring intermissions were used to interpret the differences in throughfall between harvested and non-harvested areas. Gross rainfall was monitored at $1 \mathrm{~min}$ intervals at site MU (1060 m a.s.l.), located $1 \mathrm{~km}$ southwest of the study site.

To evaluate the precise radiation budget at the surface, four radiation components were measured using radiometers, which were attached to a horizontal metal pipe $2 \mathrm{~m}$ above the ground (Fig. 1c). The ground surface temperature was estimated from upward longwave radiation using the StefanBoltzmann law. The ground surface temperature was also observed by temperature data loggers, which were covered by small cobbles to prevent being directly hit by solar insolation, as a backup to the radiometers. Because the temperature measured by temperature data loggers has a lower spatial representation than the upward longwave radiometers, temperatures estimated from upward longwave radiation were preferentially used in our analysis. The ground surface temperature in the period without radiometer data was estimated by substituting temperature from temperature loggers into the regression equations obtained from periods when radiometer data were available. Ground temperatures at $0.05,0.15$, and $0.3 \mathrm{~m}$ depths were monitored by thermocouples. Snow depth was observed by ultrasonic sensors, which were installed on poles at heights of about $1.7 \mathrm{~m}$ and measured the distance between the snow surface (ground surface in snowfree periods) and the sensors. Air temperature was observed by thermo-hygrographs.

\subsection{Frost heave and soil creep velocity}

The occurrence of frost heave was detected by extensometers and time lapse cameras (TLCs). The main body of the extensometer was fixed to a metal beam located $0.4 \mathrm{~m}$ above the ground surface. At the lower end of the extensometer, a detection part extended down and was attached to the ground surface. The output voltage was converted to displacement (along a line running perpendicularly to the ground surface) using a calibration formula specific to each sensor. The biases caused by temperature changes in the non-freezing periods were corrected for using air temperature monitored at both sites. However, a maximum bias, due to changes in the air temperature, of $5 \mathrm{~mm}$ remained in site $\mathrm{CC}$ following correction equations as a result of large diurnal changes in air temperature.

TLCs were set $0.2 \mathrm{~m}$ above the ground after forest harvesting (in November 2012), and photographed the ground surface around the extensometers in the daytime. Temporal changes in the ground surface level were interpreted by image analyses using scales placed on the ground surface. Frost heave values observed by the extensometers were generally lower than those from the camera images because of penetration of the head of the detection part into the loose ground surface. Therefore, we converted the displacement values recorded by the extensometers to actual displacement by applying the calculated relationship between the displacement recorded by the extensometers and that from the camera images. Velocity of the ground surface sediment in the slope direction associated with the soil creep was estimated by comparing the location of at least three pebbles on the ground surface in images. In site $\mathrm{CC}$, images in the period 23 June to 1 December 2012, and after 5 March could not be used for analysis of frost heave and soil creep, because the ground surface sediment was completely covered by living and dead grasses. Data at site NC are not available in the period 11 May to 29 July 2014, due to TLC mechanical trouble and loss of data due to a crash of the digital storage. Because of limitations in the resolution of camera images (about 1 to $1.5 \mathrm{~mm} \mathrm{pixel}^{-1}$ in the study area), we were only able to identify frost heave and soil creep with a displacement of $>1-2 \mathrm{~mm}$.

\subsection{Sediment flux}

Sediment traps were installed at all five monitoring plots to record the sediment flux by ground surface and near-surface processes, such as soil creep, dry ravel, rockfall, and surface erosion. The locations of all sediment traps in site $\mathrm{CC}$ were over $5 \mathrm{~m}$ away from branches piled up by the forestry operation, because sediment flux just below the piled branches was likely to be lower than the surroundings. Vertical wire meshes $(1.75 \mathrm{~m}$ wide) were secured on the hillslope using steel bars (Figs. 1c, 3). Synthetic sheets were placed on the upslope side of the wire mesh and adjacent to the ground 
Table 2. Observation periods of sediment traps (periods 1 to 27) and operation periods of other monitoring devices. $R$, TLC, and RG indicate radiometers, time lapse cameras, and rain gauges, respectively. Monitoring of sediment traps in site CC was suspended during the harvesting period. Monitoring periods of ultrasonic sensors for snow depth, thermocouples, and extensometers were the same as that of radiometers.

\begin{tabular}{|c|c|c|c|c|c|c|c|c|c|}
\hline \multirow[t]{2}{*}{ Periods } & \multirow[t]{2}{*}{ Start date } & \multirow[t]{2}{*}{ End date } & \multirow{2}{*}{$\begin{array}{r}\text { Duration } \\
\text { (day) }\end{array}$} & \multirow[t]{2}{*}{ Season } & \multicolumn{5}{|c|}{ Other monitoring device } \\
\hline & & & & & $R$ & $\begin{array}{l}\text { TLC } \\
\text { (CC) }\end{array}$ & $\begin{array}{l}\text { TLC } \\
\text { (NC) }\end{array}$ & $\begin{array}{l}\mathrm{RG} \\
\text { (CC) }\end{array}$ & $\begin{array}{c}\mathrm{RG} \\
(\mathrm{NC})\end{array}$ \\
\hline 1 & 22 Jun 2011 & $5 \mathrm{Jul} 2011$ & 13 & Rainfall & & & & & $\mathrm{O}$ \\
\hline 2 & $5 \mathrm{Jul} 2011$ & 23 Aug 2011 & 49 & Rainfall & & & & & $\mathrm{O}$ \\
\hline 3 & 23 Aug 2011 & 7 Oct 2011 & 37 & Rainfall & & & & $\mathrm{O}$ & \\
\hline 4 & 7 Oct 2011 & 4 Nov 2011 & 36 & Rainfall & & & & $\mathrm{O}$ & $\mathrm{O}$ \\
\hline 5 & 4 Nov 2011 & 25 Nov 2011 & 21 & Rainfall & & & & & $\mathrm{O}$ \\
\hline 6 & 25 Nov 2011 & 13 Dec 2011 & 18 & FT & & & & $\mathrm{O}$ & $\mathrm{O}$ \\
\hline 7 & 13 Dec 2011 & 24 Jan 2012 & 42 & FT & & & & $\mathrm{O}$ & $\mathrm{O}$ \\
\hline 8 & 24 Jan 2012 & 2 Feb 2012 & 9 & FT & $\mathrm{O}$ & & & $\mathrm{O}$ & $\mathrm{O}$ \\
\hline 9 & 2 Feb 2012 & 20 Feb 2012 & 18 & FT & $\mathrm{O}$ & & & $\mathrm{O}$ & $\mathrm{O}$ \\
\hline 10 & $20 \mathrm{Feb} 2012$ & 6 Mar 2012 & 15 & FT & $\mathrm{O}$ & & & $\mathrm{O}$ & $\mathrm{O}$ \\
\hline 11 & 6 Mar 2012 & 8 May 2012 & 63 & FT and rainfall & $\mathrm{O}$ & & & $\mathrm{O}$ & $\mathrm{O}$ \\
\hline 12 & 8 May 2012 & 10 Aug 2012 & 94 & Rainfall & \multicolumn{4}{|c|}{ Harvesting period } & $\mathrm{O}$ \\
\hline 13 & 10 Aug 2012 & 25 Sep 2012 & 46 & Rainfall & & \multicolumn{3}{|c|}{ Harvesting period } & \\
\hline 14 & 25 Sep 2012 & 2 Oct 2012 & 7 & Rainfall & & \multicolumn{3}{|c|}{ Harvesting period } & \\
\hline 15 & 2 Oct 2012 & 19 Nov 2012 & 48 & Rainfall & & & & & \\
\hline 16 & 19 Nov 2012 & 27 Dec 2012 & 38 & FT & $\mathrm{O}$ & $\mathrm{O}$ & $\mathrm{O}$ & $\mathrm{O}$ & $\mathrm{O}$ \\
\hline 17 & 27 Dec 2012 & 28 Jan 2013 & 32 & FT & $\mathrm{O}$ & $\mathrm{O}$ & $\mathrm{O}$ & $\mathrm{O}$ & $\mathrm{O}$ \\
\hline 18 & 28 Jan 2013 & 4 Mar 2013 & 35 & FT & $\mathrm{O}$ & $\mathrm{O}$ & $\mathrm{O}$ & $\mathrm{O}$ & $\mathrm{O}$ \\
\hline 19 & 4 Mar 2013 & 21 Mar 2013 & 17 & Rainfall & $\mathrm{O}$ & $\mathrm{O}$ & $\mathrm{O}$ & $\mathrm{O}$ & $\mathrm{O}$ \\
\hline 20 & 21 Mar 2013 & 27 May 2013 & 67 & Rainfall & & $\mathrm{O}$ & $\mathrm{O}$ & $\mathrm{O}$ & $\mathrm{O}$ \\
\hline 21 & 27 May 2013 & 20 Aug 2013 & 85 & Rainfall & & $\mathrm{O}$ & & $\mathrm{O}$ & $\mathrm{O}$ \\
\hline 22 & 20 Aug 2013 & 12 Nov 2013 & 84 & Rainfall & & & & $\mathrm{O}$ & \\
\hline 23 & 12 Nov 2013 & 17 Jan 2014 & 66 & FT & & $\mathrm{O}$ & & $\mathrm{O}$ & $\mathrm{O}$ \\
\hline 24 & 17 Jan 2014 & 4 Apr 2014 & 77 & FT & & $\mathrm{O}$ & & $\mathrm{O}$ & $\mathrm{O}$ \\
\hline 25 & 4 Apr 2014 & $29 \mathrm{Jul} 2014$ & 116 & Rainfall & & & & $\mathrm{O}$ & $\mathrm{O}$ \\
\hline 26 & 29 Jul 2014 & 11 Nov 2014 & 105 & Rainfall & & & $\mathrm{O}$ & $\mathrm{O}$ & \\
\hline 27 & 11 Nov 2014 & 25 Маy 2015 & 195 & FT & & & & $\mathrm{O}$ & \\
\hline
\end{tabular}

surface to facilitate capture of finer sediments (e.g., sand and silt), as well as to distinguish between residual soil and sediment transported from the upper slopes. The sides of the synthetic sheets adjacent to the ground surface were closed to prevent removal of fine sediment in the trap by rainfall and surface water (Fig. 3). Since the synthetic sheets were fixed on the ground surface, sediment traps observed sediment flux on the ground surface, rather than soil creep in the subsoil (>0.05 $\mathrm{m}$ in depth).

Sediment stored in the traps was collected 27 times between 5 July 2011 and 25 May 2015 (Table 2). Sampling intervals varied from 7 to 195 days, and generally we attempted to capture the major periods of potential seasonal differences (i.e., periods of the seasonal rainfall front, typhoon seasons, and extreme periods of freezing and thawing) that would affect the type of sediment transport. We classified the 27 sampling periods into rainfall seasons (basically from April to November) and freeze-thaw seasons (basically from December to March) in order to investigate seasonal differences in the sediment transport characteristics (Table 2). While sed- iment traps aimed to observe sediment flux over a hillslope scale and can be affected by the amount and spatial distribution of branches left in the harvested area, TLCs aimed to monitor soil creep within small-scale target areas $\left(<1 \mathrm{~m}^{2}\right)$. Sediment larger than $30 \mathrm{~mm}$ stored by the traps was weighed in the field using a spring balance. Sediment smaller than $30 \mathrm{~mm}$ was taken to the laboratory. After drying in a drying oven at a temperature of $105^{\circ} \mathrm{C}$ for about $8 \mathrm{~h}$, large organic materials $(>4 \mathrm{~mm}$ ) were removed by hand. Then, grain-size distribution was analyzed using sieves with mesh sizes of 4 , 8 , and $16 \mathrm{~mm}$. In this study, sediment flux was calculated from the weight of the sediment captured by traps divided by the width of traps $(1.75 \mathrm{~m})$ and sampling intervals. Because the topography (i.e., contributing area, slope gradient) and grain size, which potentially affects sediment flux, were different between sites CC and NC, the impact of forest harvesting cannot be evaluated by comparing the sediment flux between the two sites. Furthermore, the effect of such differences in the site conditions cannot be simply removed via division of the sediment flux by the contributing area and 
Table 3. List of monitoring devices.

\begin{tabular}{|c|c|c|c|c|c|}
\hline $\begin{array}{l}\text { Monitoring } \\
\text { item }\end{array}$ & Devices & $\begin{array}{l}\text { Model } \\
\text { (manufacturer) }\end{array}$ & $\begin{array}{r}\text { Interval } \\
\text { (minute) }\end{array}$ & Accuracy & Location \\
\hline Rainfall & $\begin{array}{l}\text { Tipping bucket } \\
\text { rain gauges }\end{array}$ & $\begin{array}{l}\text { Rain collector II } \\
\text { (Davis instruments) }\end{array}$ & 1 & $4 \%$ & CC, NC (Fig. 1) \\
\hline $\begin{array}{l}\text { Four radiation } \\
\text { components }\end{array}$ & Net radiometers & $\begin{array}{l}\text { CNR } 4 \text { (Kipp \& } \\
\text { Zonen Co.) }\end{array}$ & 10 & $4 \%$ & CCS, NCS \\
\hline Air temperature & $\begin{array}{l}\text { Thermo- } \\
\text { hygrographs }\end{array}$ & $\begin{array}{l}\text { Hobo Pro v2 } \\
\text { U23 (Onset Co.) }\end{array}$ & 10 & $0.2^{\circ} \mathrm{C}$ & CCS, NCS \\
\hline $\begin{array}{l}\text { Ground surface } \\
\text { temperature }\end{array}$ & $\begin{array}{l}\text { Temperature data } \\
\text { loggers }\end{array}$ & $\begin{array}{l}\text { TidbiT v2 } \\
\text { (Onset Co.) }\end{array}$ & 10 & $0.2^{\circ} \mathrm{C}$ & All plots \\
\hline $\begin{array}{l}\text { Ground } \\
\text { temperature }\end{array}$ & Thermocouples & - & 10 & $1^{\circ} \mathrm{C}$ & CCR, NCR \\
\hline Snow depth & Ultrasonic sensors & $\begin{array}{l}\text { U-GAGE } \\
\text { T30UXUB (Banner } \\
\text { Engineering Corp.) }\end{array}$ & 10 & $0.25 \%$ & CCR, NCR \\
\hline Frost heave & Extensometers & $\begin{array}{l}\text { DT-100A (Kyo-WA } \\
\text { Co.) }\end{array}$ & 60 & $0.5 \%$ & CCR, NCR \\
\hline $\begin{array}{l}\text { Frost heave, } \\
\text { soil creep }\end{array}$ & Time lapse camera & $\begin{array}{l}\text { GardenWatchCam } \\
\text { (Brinno) }\end{array}$ & 10 & - & CCR, NCR \\
\hline
\end{tabular}

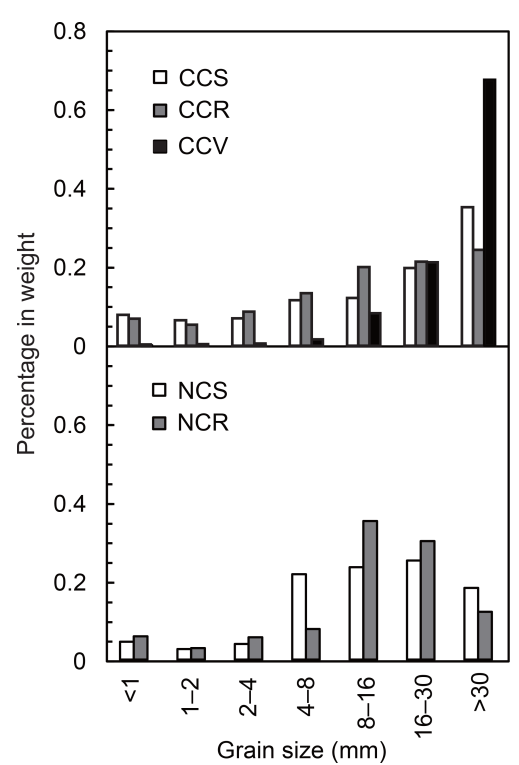

Figure 2. Grain-size distribution of the ground surface sediment around monitoring plots.

other topographic indexes because of the spatial discontinuity and complexity of the hydrological processes (Cerdan et al., 2008; Gomi et al., 2008). Therefore, we evaluated the impact of forest harvesting on the sediment flux by comparing the before and after harvesting results in each site.

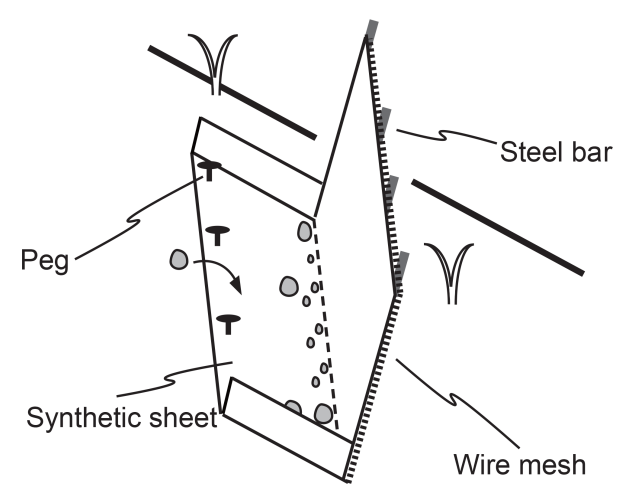

Figure 3. Illustration of sediment traps.

\section{Results}

\subsection{Microclimate and freeze-thaw conditions}

Clear changes in the winter microclimate conditions, including ground surface temperature, net radiation, and snow depth, following forest harvesting were monitored in site CC (Figs. 4, 5). Before forest harvesting, ground surface temperature at $\mathrm{CC}$ in the middle of winter (January and February) was lower than that at $\mathrm{NC}$ due to the higher elevation and westerly slope orientation (Fig. 4). Diurnal range in the ground surface temperature at $\mathrm{NC}$ after the harvesting period did not differ clearly from that before the harvesting period (e.g., 1.6 and $1.0^{\circ} \mathrm{C}$, respectively), while the diurnal range at $\mathrm{CC}$ after the harvesting period was notably higher than that before the harvesting period (average 15.9 and $2.7^{\circ} \mathrm{C}$, respectively, Fig. 4). In site $\mathrm{CC}$, changes in the ground surface temperature at 07:00 and 14:00 local time (LT) following for- 


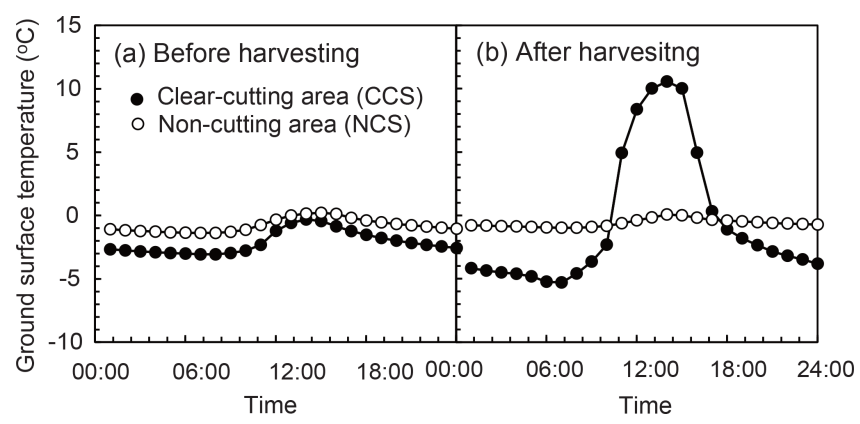

Figure 4. Average ground surface temperature before and after harvesting at sites CC (CCS) and NC (NCS). (a) Before clear-cutting in the period 1 January to 29 February 2012. (b) After clear-cutting in the period 1 January to 28 February 2013.

est harvesting were -2.4 and $+10.8^{\circ} \mathrm{C}$, respectively (Fig. 4). Net radiation in site $\mathrm{CC}$ is lower than that in site $\mathrm{NC}$ in the morning; monthly averages of the net radiation at 06:00 in February 2013 at $\mathrm{CC}$ and $\mathrm{NC}$ were 2.6 and $33.2 \mathrm{~W} \mathrm{~m}^{-2}$, respectively (Fig. 5b). In contrast, net radiation of $\mathrm{CC}$ in the daytime (e.g., a monthly average of $266.4 \mathrm{~W} \mathrm{~m}^{-2}$ at 13:00 in February 2013) was notably higher than that of NC (a monthly average of $14.7 \mathrm{~W} \mathrm{~m}^{-2}$ at 13:00 in February 2013; Fig. 5b).

Snow depth and snow cover duration were also different between sites CC and NC. Snow depth in site CC, where the forest canopy which had previously intercepted snow was removed by forest harvesting, was higher than that in NC following heavy snowfall events (e.g., 0.28 and $0.15 \mathrm{~m}$ in CC and NC on 15 January 2013, respectively, Fig. 5a). Meanwhile, duration of the snow cover in site $\mathrm{CC}$ was shorter than in $\mathrm{NC}$ because snow depth decreased at a higher rate in site $\mathrm{CC}$ than in site NC.

Large diurnal changes in the ground temperature in CC (Fig. 4) resulted in a high frequency of freeze-thaw cycles at the ground surface (54 times in the period 1 January to 28 February 2013, Fig. 5c). In the same period, 13 diurnal freeze-thaw cycles were observed at a depth of $0.05 \mathrm{~m}$, whereas just three cycles were observed at a depth of $0.15 \mathrm{~m}$ (Fig. 6b, c). Ground temperature did not drop below $0{ }^{\circ} \mathrm{C}$ at $0.3 \mathrm{~m}$ depth. In contrast, freeze-thaw cycles at the ground surface and $0.05 \mathrm{~m}$ depth in site $\mathrm{NC}$ were characterized by a low frequency (11 times at the ground surface in the period 1 January to 28 February 2013) and long duration (longer than a week, Fig. $6 b, d$ ). Ground temperature at a depth of $0.3 \mathrm{~m}$ in site $\mathrm{NC}$ was also below $0{ }^{\circ} \mathrm{C}$ for several days during the long periods of snow cover (Figs. 5a, 6d). Thus, forest harvesting changed deep seasonal freeze-thaw in the conifer artificial forest (depth of $>0.15 \mathrm{~m}$ ) to shallow diurnal freezethaw (depth $<0.05 \mathrm{~m}$ ) (Fig. 6). The diurnal freeze-thaw cycle frequently occurred in site $\mathrm{CC}$ until the end of April. In comparison, ground temperature seldom fell below $0^{\circ}$ in site $\mathrm{NC}$ in April (Fig. 7c).
In the seasons without freeze-thaw activities (rainfall seasons), changes in the microclimate conditions following forest harvesting were evident in the throughfall amount (Fig. 8). Differences in the hourly rainfall intensity between sites $\mathrm{CC}$ and $\mathrm{NC}$ were not clear before forest harvesting (Fig. 8a), while the rainfall intensity in CC was 0 to $3 \mathrm{~mm} \mathrm{~h}^{-1}$ higher than that in $\mathrm{NC}$ after forest harvesting (Fig. 8b). The duration ratio for which throughfall in $\mathrm{CC}$ exceeded that in $\mathrm{NC}$ was increased from 0.50 to 0.62 by the forest harvesting.

\subsection{Frost heave and soil creep}

In winter, ground surface level changes frequently due to frost heave in site $\mathrm{CC}$, except for during periods of snow cover, while frost heave in site $\mathrm{NC}$ has a longer cycle (Fig. 6e). The uplifting period of the ground surface in site $\mathrm{NC}$ roughly corresponded to the freezing period of the subsoil (i.e., $0.05 \mathrm{~m}$ depth). Velocity of the ground surface sediment by soil creep observed by a TLC in site CC was generally high $\left(>2 \mathrm{~mm} \mathrm{day}^{-1}\right)$ on the days with frost heave (Fig. 6e, f), and was significantly higher than in site NC (generally $<1 \mathrm{~mm} \mathrm{day}^{-1}$ ).

In site $\mathrm{CC}$, frost heave was less frequent in early spring (March), with almost no frost heave occurring in late spring (late April to March; Fig. 7). Frost heave in this period was only monitored by the TLC, as frost heave height in March was lower than the bias of extensometers $(\leq 5 \mathrm{~mm})$. No changes in the ground surface level were identified in site NC. Displacement of ground surface sediment in site CC still occurred frequently until the end of April. High velocity $\left(>2 \mathrm{~mm} \mathrm{day}^{-1}\right.$ ) was not only observed on frost heave days but also on other days, including those with no precipitation. Velocity of the ground surface sediment in site NC during the spring periods (e.g., average 0.08 in the period 15 March to 15 May 2013) was much lower than in site CC (e.g., average 0.80 in the same period, Fig. 7).

During the rainfall seasons, sediment transport was triggered by rainfall in both CC and NC (Fig. 9). Both sites showed a similar trend of high velocity of the ground surface sediment $\left(>2 \mathrm{~mm} \mathrm{day}^{-1}\right)$ on days with heavy rainfall events (Fig. 9). The rainfall threshold for such high velocities was roughly given by a maximum hourly rainfall intensity of $>5 \mathrm{~mm} \mathrm{~h}^{-1}$ and a total rainfall depth of $>40 \mathrm{~mm}$ for both sites, although there is some uncertainty because of one plot exceeding the threshold with a creep velocity of $<2 \mathrm{~mm} \mathrm{day}^{-1}$ (Fig. 10).

\subsection{Sediment flux}

Sediment flux before forest harvesting was spatially variable between monitoring plots (Fig. 11, Table 4). During the monitoring period, sediment flux at plot CCV, where sediment from surrounding slopes accumulates due to its large contributing area (Table 1), was notably higher than that at the other monitoring plots (Table 4). Differences in the sediment 


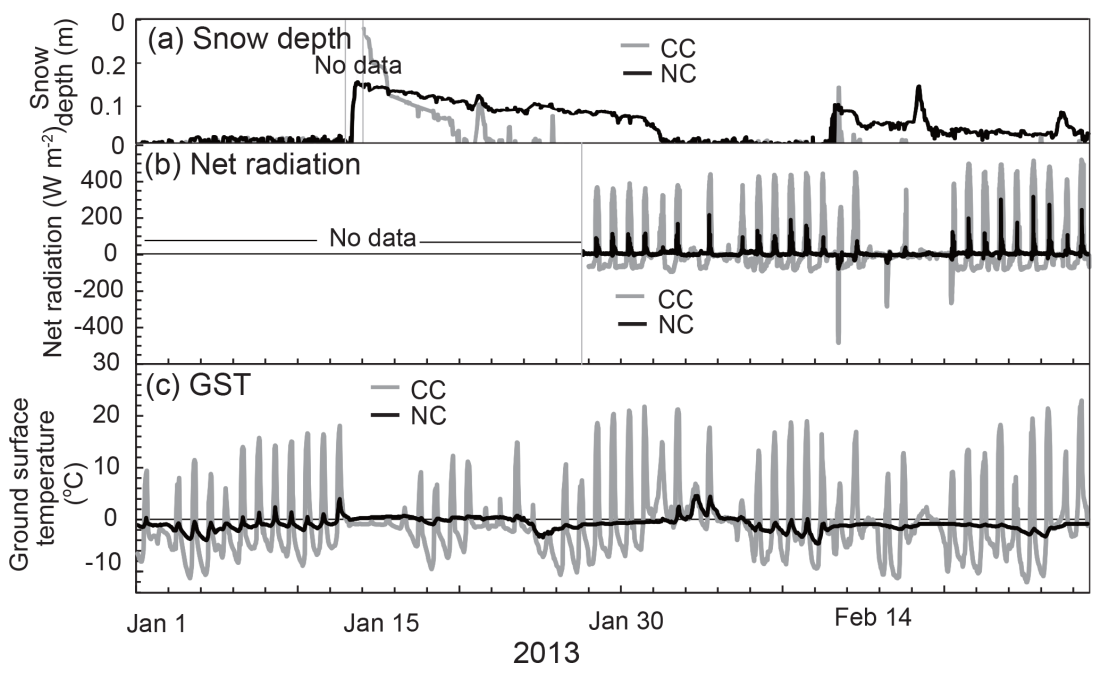

Figure 5. Comparison of microclimate conditions between sites CC and NC in winter (1 January to 28 February 2013). (a) Snow depth measured by ultrasonic sensors at sites CC (CCR) and NC (NCR). (b) Net radiation measured by net radiometers in sites CC (CCS) and NC (NCS). (c) Ground surface temperature (GST) in sites CC (CCS) and NC (NCS).

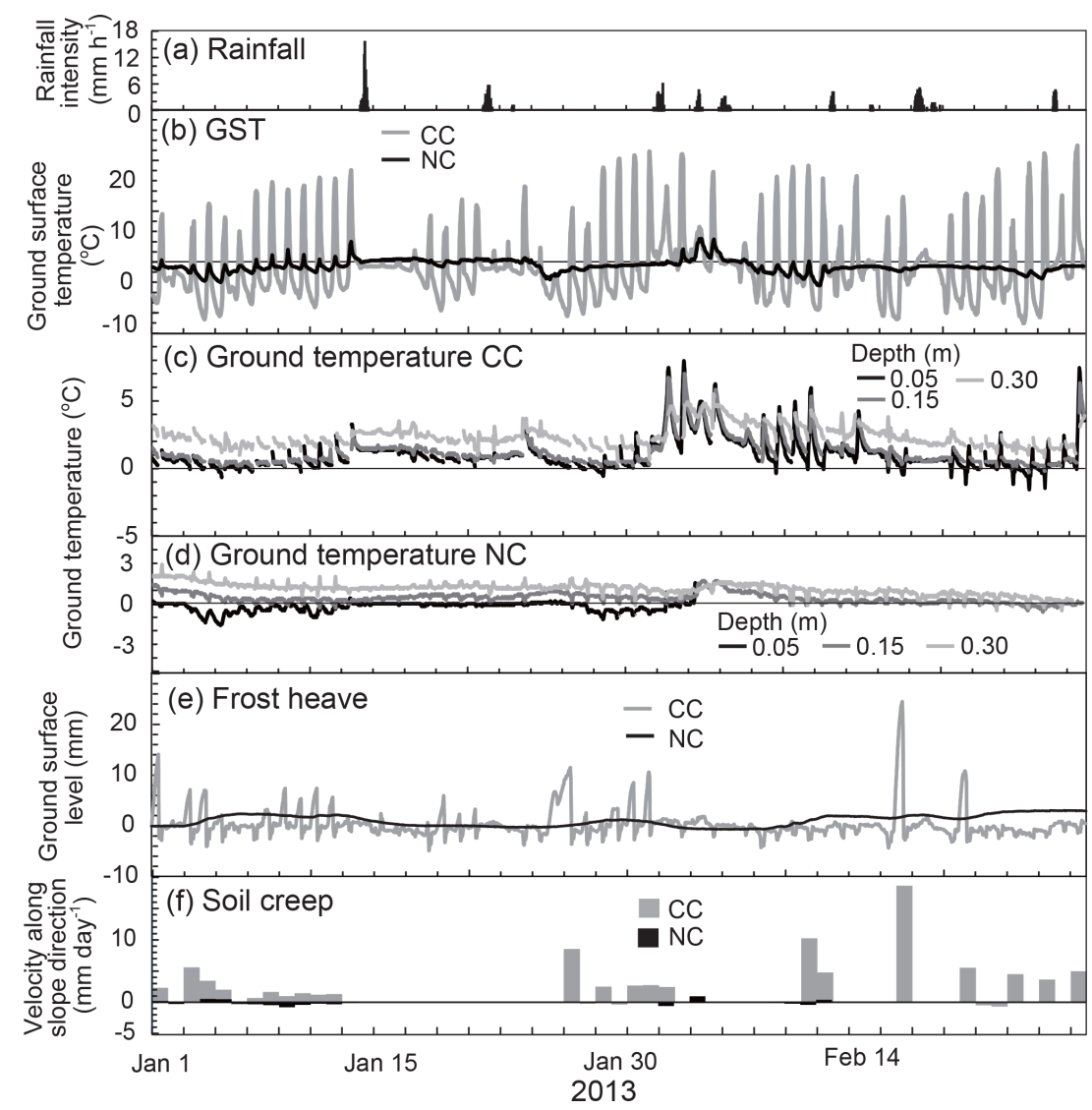

Figure 6. Frost heave and soil creep activities in winter (1 January to 28 February 2013). (a) Rainfall intensity at site MU. (b) Ground surface temperature (GST) in sites CC (CCS) and NC (NCS). (c) Ground temperature in CC (CCR) measured by thermocouples. (d) Ground temperature in NC (NCR) measured by thermocouples. Monitoring of the ground temperature at $5 \mathrm{~cm}$ depth was interrupted by a defect of the thermocouple from 4 February onwards. (e) Changes in the ground surface level measured by extensometers at CC (CCR) and NC (NCR). (f) Velocity of ground surface sediment along the slope direction obtained from TLC images. 


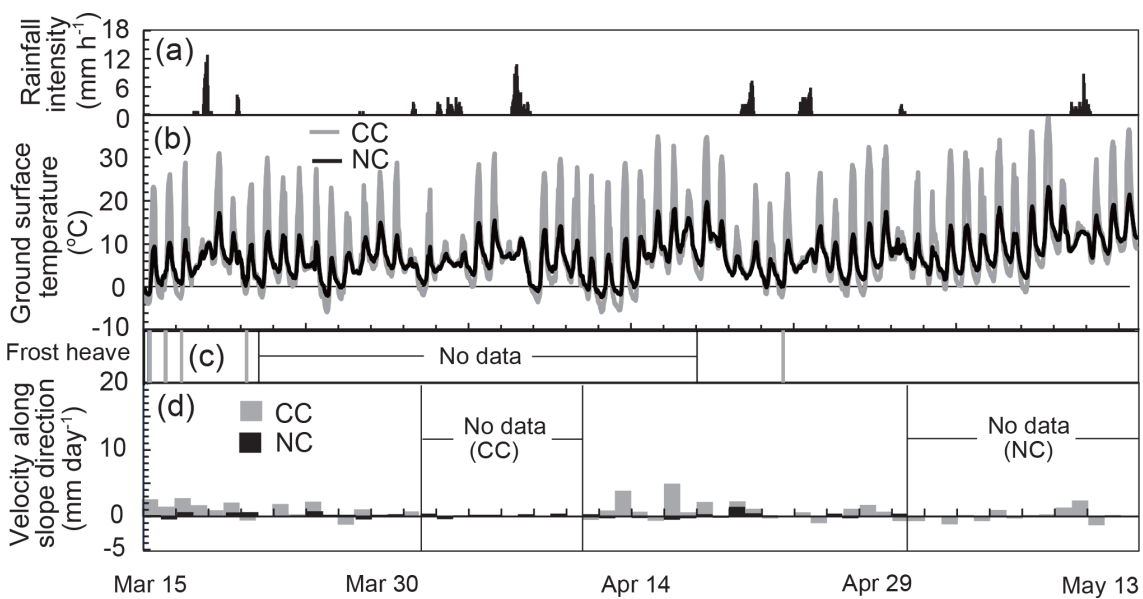

Figure 7. Comparison of microclimate conditions and sediment transport activities between sites CC and $\mathrm{NC}$ in spring (15 March to 15 May 2013). (a) Hourly rainfall intensity at site MU. (b) Ground surface temperature in sites CC (CCS) and NC (NCS). (c) Timing of frost heave in CCR monitored by TLC. Uplifting of the ground surface was not observed at NC in this period. (d) Velocity of ground surface sediment by soil creep in CC (plot CCR) and NC (plot NCR) obtained from TLC images.
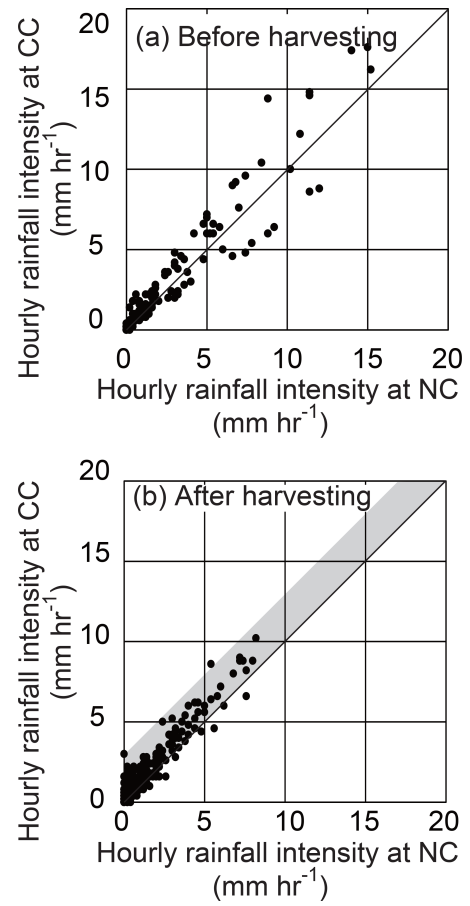

Figure 8. Comparison of the hourly rainfall intensity between sites $\mathrm{NC}$ and CC. (a) Comparison before forest harvesting (25 August to 2 September and 4 November to 30 November 2012). The rainfall monitoring was disrupted by damage to the rain gauge associated with a typhoon (2 September to 7 October) and by a malfunction of the data logger (7 October to 3 November). (b) Comparison after forest harvesting (4 April to 3 July 2012). The range where rainfall intensity at $\mathrm{CC}$ is 0 to $3 \mathrm{~mm} \mathrm{~h}^{-1}$ higher than at NC is shaded. flux were not clear between straight and ridge-shaped slopes, despite the contributing area of plots at straight slopes being larger than those at ridge-shaped slopes. Sediment flux in CC was slightly higher than that in $\mathrm{NC}$ when we compare plots with the same shape, potentially because of the higher slope gradient (Table 1). Sediment flux in the winter (25 November 2011 to 6 March 2012) was clearly higher than that in the rainfall seasons (22 June to 24 November 2011) at three plots (CCR, CCV, NCR; Table 4). In addition, if two exceptionally large boulders $(>1 \mathrm{~kg})$, which occupied $50.0 \%$ of the sediment flux in the rainfall season, were excluded, then sediment flux in the winter at NCS $\left(11.1 \mathrm{~kg} \mathrm{~m}^{-1} \mathrm{day}^{-1}\right)$ was higher than that in the rainfall season $\left(8.9 \mathrm{~kg} \mathrm{~m}^{-1}\right.$ day $\left.^{-1}\right)$. Coarse sediment $(>16 \mathrm{~mm})$ occupied a large portion of the sediment flux in both rainfall and freeze-thaw seasons at all observation plots except at CCR during rainfall seasons (Fig. 12). Sediment flux of coarse sediment $(>16 \mathrm{~mm})$ in freeze-thaw seasons was higher than that in rainfall seasons at all plots (Fig. 12). In contrast, sediment flux of fine sediment $(<4 \mathrm{~mm})$ during rainfall seasons was higher than in freeze-thaw seasons at all plots in $\mathrm{CC}$ before forest harvesting (Fig. 12a-f) and at all plots in NC (Fig. 12g-j).

Sediment flux in site CC after the 2012 forest harvesting was lower than that before the harvesting both during rainfall and freeze-thaw seasons (Fig. 11, Table 4). Decreases in the sediment flux of all grain-size classes were identified (Fig. 12a-f). In contrast, changes in the sediment flux before and after the harvesting period were not clear in site NC (Fig. 11, Table 4). The sediment flux of fine sediment during rainfall seasons was lower than that in freeze-thaw seasons at all of the plots in site CC after forest harvesting, despite the sediment flux of fine sediment being higher during rainfall seasons than freeze-thaw seasons before harvesting (Fig. 12g-j). 

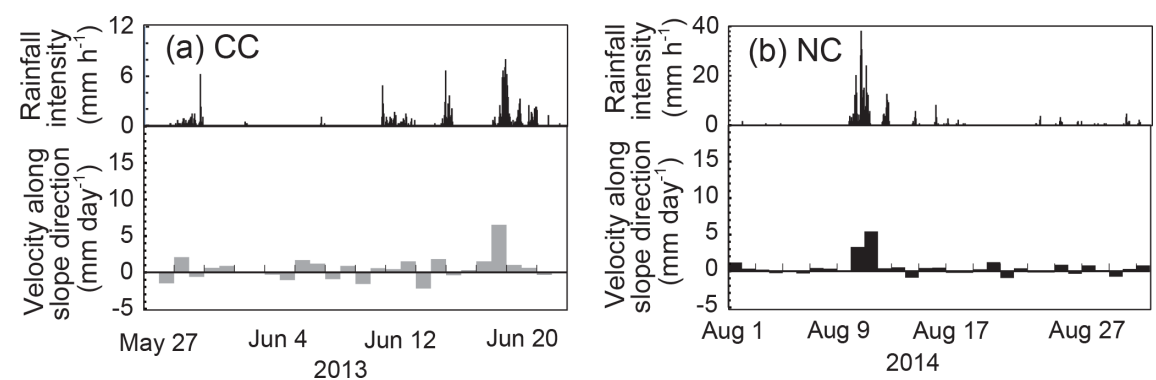

Figure 9. Velocity of ground surface sediment during rainfall seasons. (a) Velocity at site CC (CCR) in the period 27 May to 23 June 2013. (b) Velocity in site NC (NCR) in the period 1 to 31 August 2014. Periods in (a) and (b) are different, because we could not successfully obtain velocity of the ground surface sediment both in CC and NC during the same heavy rainfall event.

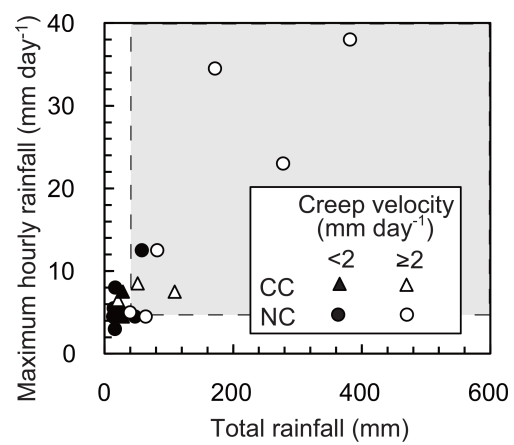

Figure 10. Comparison between total rainfall depth and maximum hourly rainfall during rainfall events with and without clear displacement of ground surface sediment (velocity of $<2$ and $\geq$ $2 \mathrm{~mm} \mathrm{day}^{-1}$, respectively). Rainfall was monitored at MU. The shaded area indicates a total rainfall depth of $>40 \mathrm{~mm}$ and an hourly rainfall intensity of $>5 \mathrm{~mm} \mathrm{~h}^{-1}$.

Sediment weight in the artificial forest (in CC before the forest harvesting, and in NC) captured by sediment traps does not have a clear relationship with total rainfall depth or maximum daily rainfall in the sampling period of sediment traps, except for CCS (Figs. 13, 14, Table 5). Sediment weight after the harvesting in $\mathrm{CC}$ does not have a clear relationship with the rainfall factors either. In site CC, sediment weight after harvesting is less than that before harvesting, when compared with periods of similar rainfall depth and intensity (Fig. 13).

\section{Discussion}

\subsection{Sediment transport characteristics in steep artificial conifer forest}

Sediment transport processes in conifer artificial forests located in humid periglacial areas can be characterized as being active both in freeze-thaw and rainfall seasons (Fig. 11). Sediment flux in freeze-thaw seasons exceeded that in rainfall seasons, indicating the importance of the periglacial processes in a humid periglacial area. Long frost heave cy-

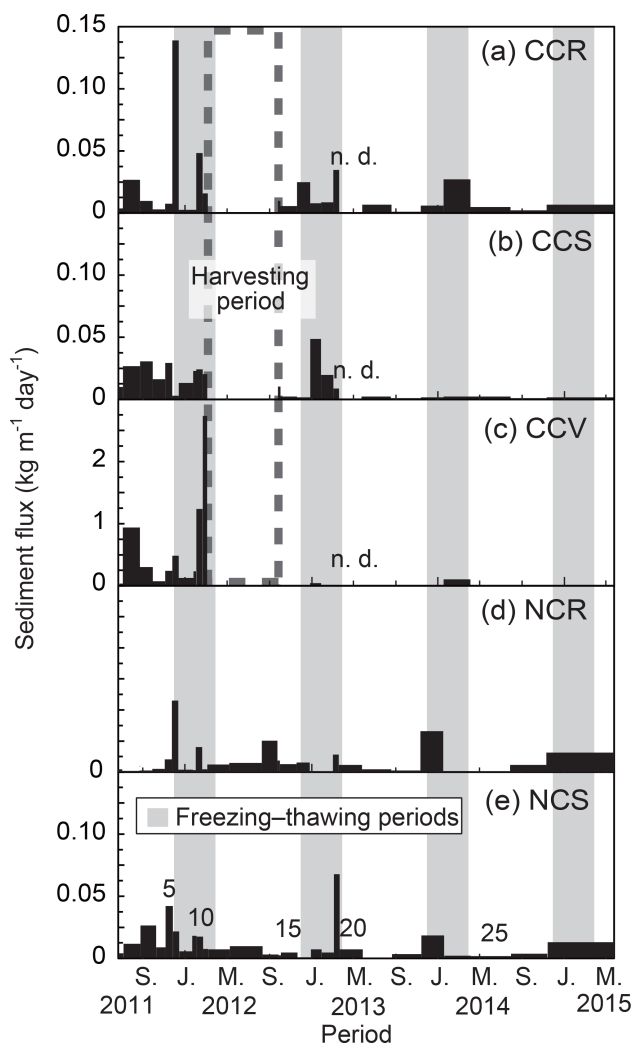

Figure 11. Temporal changes in the sediment flux: (a) plots CCR, (b) CCS, (c) CCV, (d) NCR, and (e) NCS. Numbers in (e) indicate sampling periods listed in Table 1 .

cles ( $>1$ week) and thick freezing layers $(0.15-0.3 \mathrm{~m}$ deep in some periods) during winter indicate that frost creep occurs in artificial conifer forest NC (Fig. 6d, e), while diurnal frost heave and needle-ice creep dominate in the deciduous broadleaf forest located in Ikawa University Forest, despite both being in the same elevation zone (Imaizumi et al., 2017). Therefore, the type of periglacial sediment transport process differs depending on the dominant tree species.

In rainfall seasons, although the timing of soil creep agrees with that of strong rainfall events (Figs. 9, 10), rainfall fac- 
Table 4. Comparison of average sediment flux in rainfall and freeze-thaw (FT) seasons before and after forest harvesting. Values in parentheses at plot NCS were calculated by excluding the weight of two exceptionally large boulders with weights of $>1 \mathrm{~kg}$.

\begin{tabular}{|c|c|c|c|c|c|c|}
\hline \multirow[t]{3}{*}{ Plots } & \multicolumn{4}{|c|}{ Sediment flux $\left(\times 10^{-3} \mathrm{~kg} \mathrm{~m}^{-1} \mathrm{day}^{-1}\right)$} & \multirow[t]{3}{*}{$\mathrm{C} / \mathrm{A}$} & \multirow[t]{3}{*}{$\mathrm{D} / \mathrm{B}$} \\
\hline & \multicolumn{2}{|c|}{ Before clear-cutting } & \multicolumn{2}{|c|}{ After clear-cutting } & & \\
\hline & $\begin{array}{r}\text { Rainfall season } \\
\text { (A) }\end{array}$ & $\begin{array}{r}\text { FT season } \\
\text { (B) }\end{array}$ & $\begin{array}{r}\text { Rainfall season } \\
\text { (C) }\end{array}$ & $\begin{array}{r}\text { FT season } \\
\text { (D) }\end{array}$ & & \\
\hline CCR & 12.1 & 35.5 & 3.6 & 12.1 & 0.29 & 0.34 \\
\hline CCS & 21.8 & 14.4 & 1.1 & 6.0 & 0.05 & 0.42 \\
\hline $\mathrm{CCV}$ & 418.1 & 753.9 & 5.4 & 20.1 & 0.01 & 0.03 \\
\hline NCR & 2.5 & 14.5 & 3.2 & 12.3 & 1.26 & 0.85 \\
\hline NCS & $\begin{array}{c}17.8 \\
(8.9)\end{array}$ & 11.1 & 3.1 & 11.1 & $\begin{array}{r}0.17 \\
(0.34)\end{array}$ & 1.01 \\
\hline
\end{tabular}

Table 5. $R$-squared and $p$-values of linear regressions between sediment weight captured by sediment traps and rainfall factors in rainfall seasons.

\begin{tabular}{|c|c|c|c|c|c|c|c|c|}
\hline \multirow[t]{3}{*}{ Plot } & \multicolumn{4}{|c|}{ Before harvesting } & \multicolumn{4}{|c|}{ After harvesting } \\
\hline & \multicolumn{2}{|c|}{$\begin{array}{l}\text { Total rainfall } \\
(\mathrm{mm})\end{array}$} & \multicolumn{2}{|c|}{$\begin{array}{l}\text { Maximum daily } \\
\text { rainfall }\left(\mathrm{mm} \mathrm{day}^{-1}\right)\end{array}$} & \multicolumn{2}{|c|}{$\begin{array}{l}\text { Total rainfall } \\
\quad(\mathrm{mm})\end{array}$} & \multicolumn{2}{|c|}{$\begin{array}{l}\text { Maximum daily } \\
\text { rainfall }\left(\mathrm{mm} \mathrm{day}^{-1}\right)\end{array}$} \\
\hline & $R^{2}$ & $P$ & $R^{2}$ & $P$ & $R^{2}$ & $P$ & $R^{2}$ & $P$ \\
\hline CCR & 0.20 & 0.45 & 0.60 & 0.13 & 0.03 & 0.75 & 0.34 & 0.23 \\
\hline $\mathrm{CCS}$ & 0.80 & 0.04 & 0.93 & 0.01 & 0.14 & 0.46 & 0.38 & 0.19 \\
\hline $\mathrm{CCV}$ & 0.24 & 0.40 & 0.64 & 0.10 & 0.08 & 0.59 & 0.27 & 0.29 \\
\hline NCR & 0.17 & 0.49 & 0.12 & 0.58 & 0.12 & 0.47 & 0.01 & 0.83 \\
\hline NCS & 0.53 & 0.16 & 0.42 & 0.24 & 0.16 & 0.41 & 0.04 & 0.67 \\
\hline
\end{tabular}

tors did not have a clear relationship with sediment transport rate (Figs. 13, 14). In addition, the periods with the highest sediment flux differed between the plots (Fig. 11). These are likely to be affected by episodic sediment supply, such as small slope failure and the release of sediment from woody debris (e.g., Kirchner et al., 2001; Imaizumi et al., 2015). In addition, some sediment transport processes (e.g., dry ravel and rockfall) are triggered not only by rainfall, but also by other mechanisms (e.g., decrease in cohesion by evaporation of soil moisture, wind, and disturbance by animals) (Verity and Anderson, 1990; Gabet, 2003), further obscuring the relationship between rainfall factors and sediment transport activities.

The ratio of coarse sediment $(>16 \mathrm{~mm}$ ) to all sediment captured by sediment traps was significantly higher than the ratio of coarse sediment in the ground surface sediment (Figs. 2, 12), implying that coarse sediment was selectively transported on the hillslope. Because the travel distance of coarse sediment as rockfall and dry ravel is longer than that of fine sediment (Dorren, 2003; Haas et al., 2012), the selective transport of coarse sediment indicates the high activity of rockfall and dry ravel. This agrees with findings in previous studies that rockfall and dry ravel are active on slopes with a similar or steeper slope gradient than the angle of repose, as is the case with our monitoring site (Gabet, 2003; Lamb et al., 2011). The ratio of fine sediment, which is selectively transported by overland flow (Heng et al., 2011; Zhao et al., 2014), in the entire sediment flux was less than its ratio in the ground surface sediment (Figs. 2, 12). Therefore, surface erosion is less important than gravitational sediment transport in the steep Ikawa University Forest.

As reported in previous studies (Roering et al., 2007; Imaizumi et al., 2017), sediment flux was spatially different depending on the slope shape (Fig. 11). Sediment flux on the valley-shaped slope, which had the largest contributing area, was higher than the straight and ridge-shaped slopes of site CC before forest harvesting (Fig. 11). The contributing area may affect rapid sediment transport with long travel distances (i.e., dry ravel and rockfall) rather than slow sediment transport (i.e., soil creep), which can be explained by local freezing and transport conditions that are unrelated to the size of the contributing area (Higashi and Corte, 1971; Matsuoka, 1998). 


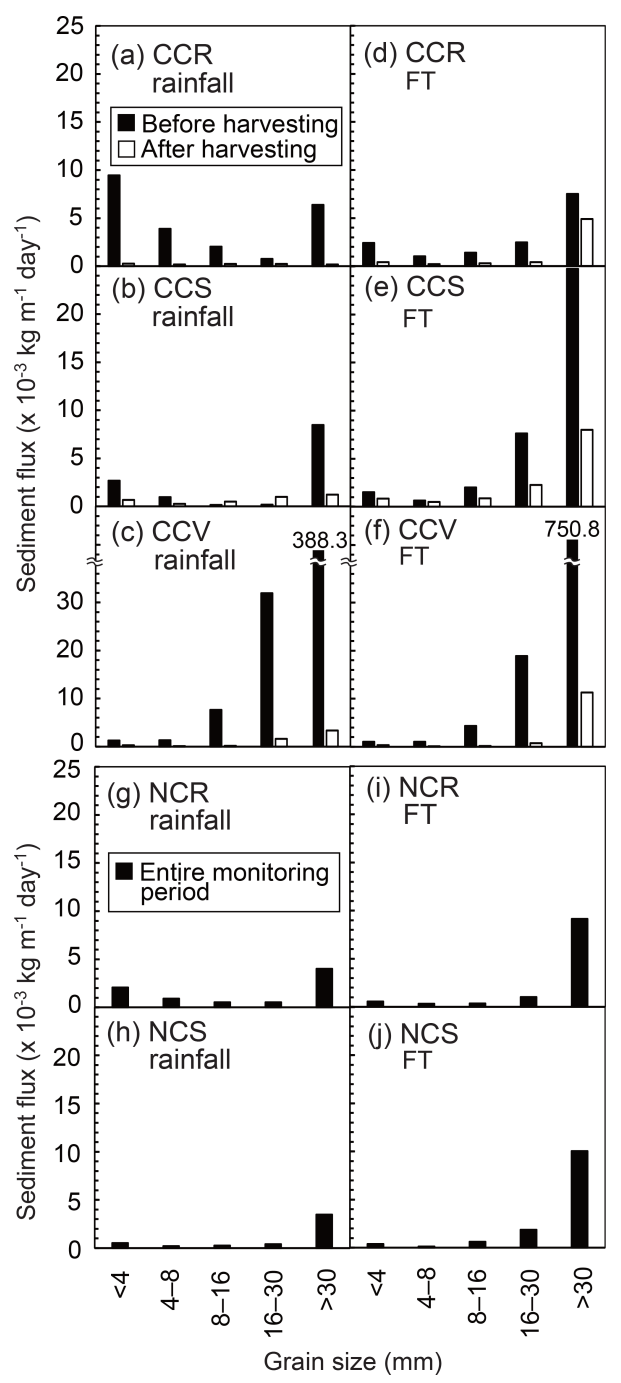

Figure 12. Average sediment flux of each grain-size class in a harvested area (site CC). (a) Sediment flux at plot CCR in rainfall periods. (b) Sediment flux at plot CCS in rainfall periods. (c) Sediment flux at plot CCV in rainfall periods. (d) Sediment flux at plot CCR in freeze-thaw periods. (e) Sediment flux at plot CCS in freezethaw periods. (f) Sediment flux at plot $\mathrm{CCV}$ in freeze-thaw periods. (g) Sediment flux at plot NCR in rainfall periods. (h) Sediment flux at plot NCS in rainfall periods. (i) Sediment flux at plot NCR in freeze-thaw periods. (j) Sediment flux at plot NCS in freeze-thaw periods.

\subsection{Impact of forest harvesting on microclimate conditions}

Ground temperature was one of the microclimate conditions most affected by forest harvesting (Figs. 4, 5c). Increases in the amplitude of net radiation (Fig. 5b), due to increases in the downward shortwave radiation during daytime and the upward longwave radiation in the morning due to the removal of the tree crown (Ueno et al., 2015), likely increased the frequency of freeze-thaw cycles after forest harvesting (Fig. 5).

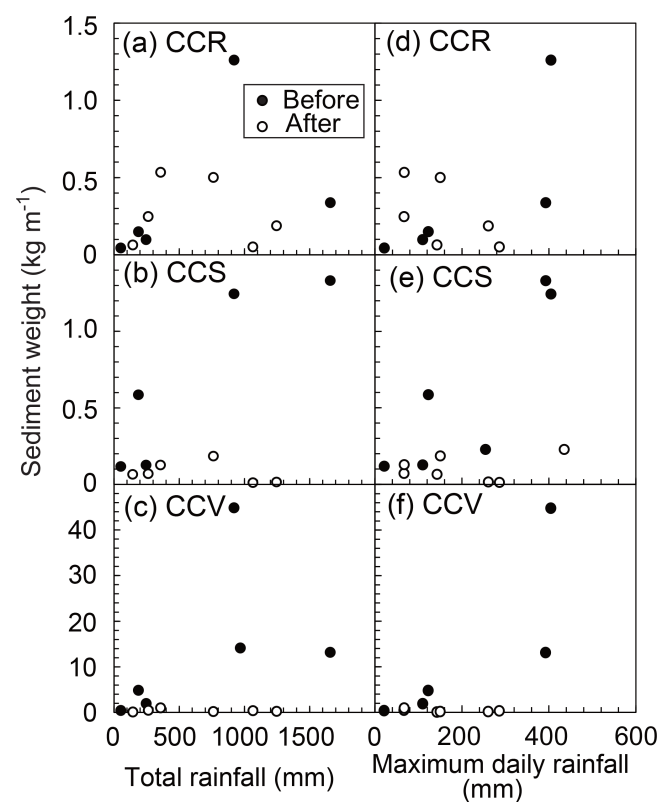

Figure 13. Comparison between rainfall factors and sediment weight captured by sediment traps during rainfall seasons in the harvested area. (a) Total rainfall and sediment weight at plot CCR. (b) Total rainfall and sediment weight at plot CCS. (c) Total rainfall and sediment weight at plot CCV. (d) Maximum daily rainfall and sediment weight at plot CCR. (e) Maximum daily rainfall and sediment weight at plot CCS. (f) Maximum daily rainfall and sediment weight at plot CCV.

Snow depth and duration of snow cover were also changed by forest harvesting (Fig. 5a). Snow depth after snowfall events in $\mathrm{CC}$ was higher than in $\mathrm{NC}$, because of the loss of canopy interception. At the same time, duration of snow cover in $\mathrm{CC}$ was significantly shorter than $\mathrm{NC}$ because of the higher downward radiation to the snow surface and higher daytime temperatures (Fig. 5) (Ueno et al., 2015). Such a short duration of snow cover also facilitated diurnal changes in the ground temperature and increased the frequency of freezethaw cycles. Snow cover also affects soil moisture, which controls frost heave and soil creep activities (Meentemeyer and Zippin, 1981; Matsuoka, 2001; Boelhouwers et al., 2003; Blankinship et al., 2014). Daytime soil moisture was generally lower during snow-free periods than snow-covered periods due to evaporation caused by insolation (Blankinship et al., 2014). Other changes to the microclimate by forest harvesting are increases in the rainfall (throughfall) intensity (Fig. 8). The loss of canopy interception by forest harvesting may have increased throughfall in site CC (Xiao et al., 2000; Fan et al., 2014).

\subsection{Impact of forest harvesting on soil creep activity}

The impact of forest harvesting on soil creep activities monitored by TLCs was most evident in winter and spring, when freeze-thaw of the groundwater directly or indirectly 


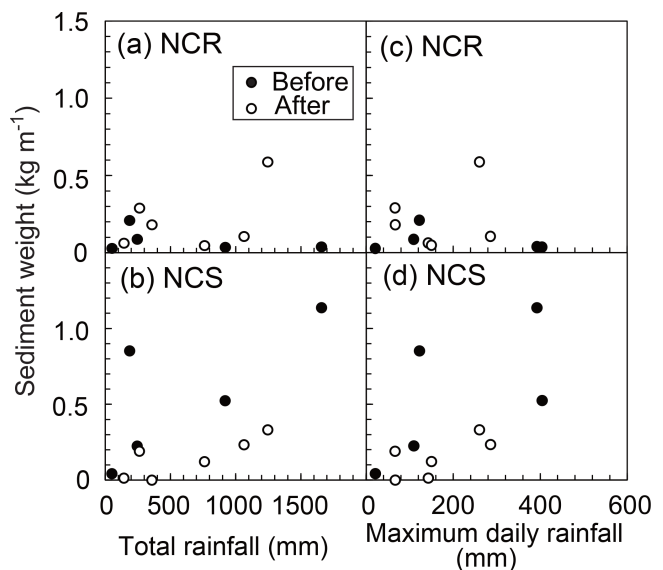

Figure 14. Comparison between rainfall factors and sediment weight captured by sediment traps during rainfall seasons in the non-harvested area. (a) Total rainfall and sediment weight at plot NCR. (b) Total rainfall and sediment weight at plot NCS. (c) Maximum daily rainfall and sediment weight at plot NCR. (d) Maximum daily rainfall and sediment weight at plot NCS.

triggered soil creep (Figs. 6, 7). In the winter, large diurnal changes in ground temperature facilitated frequent frost heave in CC, resulting in the high velocity of soil creep seen (Fig. 6) (Ueno et al., 2015). Forest harvesting changed the type of sediment transport from seasonal frost creep, which is common in seasonal freeze-thaw areas with a thick freezing depth, to needle-ice creep, which is observed in areas with shallow diurnal freeze-thaw activity (Fig. 13) (Boelhouwers, 1998; Matsuoka, 2001; Imaizumi et al., 2015).

In site CC, soil creep velocity in early spring (from late March to April), when the frequency of freeze-thaw cycles had decreased, was still higher than that in NC (Fig. 7). High soil creep velocity just after freeze-thaw seasons was also observed in a natural deciduous forest in Ikawa University Forest, where diurnal freeze-thaw is active because of leaf fall in the winter season (Imaizumi et al., 2017). High soil creep velocity in early spring is likely due to the destruction of the soil structure caused by frequent freeze-thaw cycles in winter (Regüés and Gallart, 2004; Kværnø and Øygarden, 2006; McCool et al., 2013).

In seasons without freeze-thaw cycles, soil creep was only identified during heavy rainfall events, excluding early spring (Figs. 8, 9). Although rainfall (throughfall) intensity in site CC was higher than that in site NC (Fig. 8), the difference in rainfall thresholds for high soil creep velocities $\left(>2 \mathrm{~mm} \mathrm{day}^{-1}\right.$ ) was not clear between the two sites (Fig. 10). The ratio of rainfall intercepted by forest canopies is low when the total rainfall depth and rainfall intensity is high (Xiao et al., 2000; Fan et al., 2014). Such low interception rates during heavy rainfall events, when soil creep is active in the study site, obscures the impact of harvesting on the rainfall threshold for soil creep. (a) Before forest harvesting

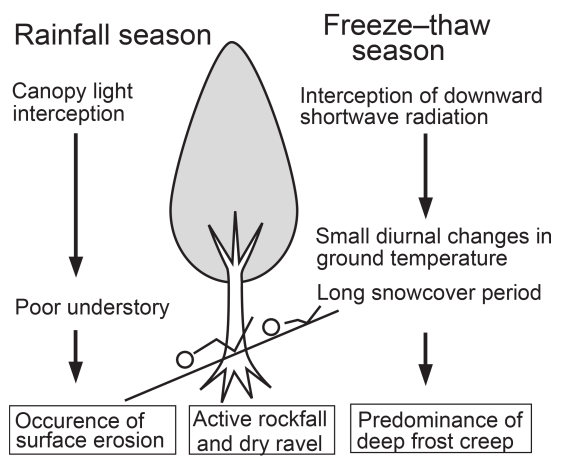

(b) After forest harvesting

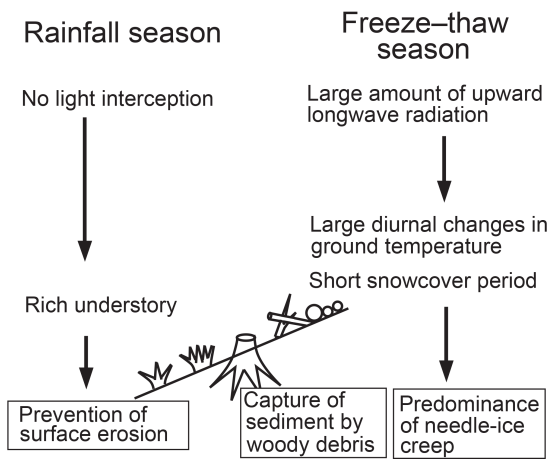

Figure 15. Difference in the hydrogeomorphic processes before and after forest harvesting on steep slopes in humid periglacial areas.

\subsection{Impact of forest harvesting on the sediment flux}

Winter sediment flux in site CC clearly decreased after forest harvesting in spite of the high soil creep velocity (Fig. 6 and Table 4). Previous studies emphasized that sediment transport activity and erosion rate in small plots are different from that on hillslope and catchment scales, because of the discontinuity of sediment transport on hillslopes (Moreno-de las Heras et al., 2010; Sidle et al., 2017). Through field surveys in CC, we identified sediment captured by the branches of harvested trees, especially where branches were piled up by forestry operations. Previous studies also reported that litters and woody debris on the ground prevented sediment transport (Hartanto et al., 2003; Liu et al., 2017). Thereby, the interruption of sediment transport by branches resulted in differences in sediment transport activity between the micro and hillslope scales, as monitored by TLCs and sediment traps, respectively. Decreases in the thickness of soil creep layers, which are affected by the thickness of the freezing layer (Matsuoka, 2001; Harris et al., 2008a), are also a potential factor affecting decreases in the sediment flux after harvesting (Fig. 6).

Following forest harvesting, sediment flux decreased during rainfall periods in site $\mathrm{CC}$, while differences in the sediment flux in $\mathrm{NC}$ before and after harvesting were not sig- 
nificant (Table 4). Decreases in the sediment flux of fine sediment, which is selectively transported by overland flow (Heng et al., 2011; Zhao et al., 2014), was clear during the rainfall seasons (Fig. 12). In site CC, the percentage of ground covered by understories, which reduce the kinetic energy of raindrops splashing soil particles (Fukuyama et al., 2010; Nanko et al., 2015), changed from $<20 \%$ to $>90 \%$ within 1 year of forest harvesting (Fig. 1). In addition, the forest canopy, which increases the size of raindrops, thus increasing their kinetic energy (Nanko et al., 2015), was removed by forest harvesting. Therefore, decreases in the sediment flux during the rainfall seasons can occur after harvesting due to decreases in surface erosion rates, together with the capture of sediment by branches and litters of harvested trees (Fig. 15).

\section{Summary and conclusion}

The impact of forest harvesting on the hydrogeomorphic processes in humid periglacial environments was investigated by intensive and comprehensive field observation of microclimate conditions and sediment transport in the southern Japanese Alps. Harvesting of artificial conifer forests clearly changed microclimate conditions and sediment transport activities during the freeze-thaw season. Canopy removal increased the diurnal amplitude of net radiation and ground temperature, and also decreased the duration of snow cover. As a result, types of soil creep changed from long-lasting frost creep to daily and frequent needle-ice creep. The velocity of ground surface sediment during winter and spring in harvested areas was higher than non-harvested areas due to high needle-ice creep activity. Sediment flux clearly decreased both in seasons with high freeze-thaw activity and seasons with heavy rainfall events. Branches of harvested trees interrupted continuous sediment transport on hillslopes. In addition, the growth of understories after forest harvesting reduced surface erosion by rain splash.

Our study clarified that forest canopy removal by forest harvesting promoted sediment transport activity by changing microclimate conditions, such as increases in the diurnal range of ground temperature, shortening of snow cover period, and increases in throughfall. However, sediment transport activity was restrained due to the entrapment of sediment by branches of harvested trees and the growth of understories. While in warm-temperate zones and tropical zones an increase in throughfall and rain splash is a particularly important impact of harvesting on sediment transport activity, in humid periglacial environments it is the microclimate conditions relating to both freeze-thaw processes and rainfall-induced processes that control sediment transport activity. Consequently, the impact of the forest harvesting on sediment transport activity is seasonally variable in humid periglacial areas. Our study also showed that ground surface conditions after harvesting, which are variable depending on the forest management procedure, affect sediment transport activities. Therefore, climate and forest harvesting procedure need to be considered when evaluating the impact of harvesting on sediment transport activities.

Data availability. The data that support the findings of this study are available from the corresponding author, Fumitoshi Imaizumi, upon reasonable request.

Author contributions. FI and KU conceived and designed the study. FI and KU preformed the analysis and wrote the paper. All of the authors conducted field motoring. FI contributed to the writing of the paper.

Competing interests. The authors declare that they have no conflict of interest.

Acknowledgements. The monitoring site and some of the rainfall data used in this study were provided by Ikawa University Forest, University of Tsukuba. We thank the technical staff of Ikawa University Forest, Toru Endo, Akira Takinami, Yoshikazu Endo, and Yusuke Ueji, who supported our fieldwork. We are also grateful to Daiki Nosaka and other students at Shizuoka University, who conducted fieldwork with us.

Edited by: Fuqiang Tian

Reviewed by: three anonymous referees

\section{References}

Benda, L.: The influence of debris flows on channels and valley floors in the Oregon Coast Range, U.S.A., Earth Surf. Process. Landf., 15, 457-466, https://doi.org/10.1002/esp.3290150508, 1990.

Blankinship, J. C., Meadows, M. W., Lucas, R. G., and Hart, S. C.: Snowmelt timing alters shallow but not deep soil moisture in the Sierra Nevada, Water Resour. Res., 50, 1448-1456, https://doi.org/10.1002/2013WR014541, 2014.

Boelhouwers, J.: Environmental controls on soil frost activity in the Western Cape Mountains, South Africa, Earth Surf. Process. Landf., 23, 211-221, 1998.

Boelhouwers, J., Holness, S., and Sumner, P.: Geomorphological characteristics of small debris flows on Junir's Kop, Marion Island, maritime sub-Antarctic., Earth Surf. Process. Landf., 25, 341-352, https://doi.org/10.1002/(SICI)10969837(200004)25:4<341::AID-ESP58>3.0.CO;2-D, 2000.

Boelhouwers, J., Holdess, S., and Summer, P.: The maritime subantarctic: a distinct periglacial environment, Geomorphology, 52, 39-55, https://doi.org/10.1016/S0169-555X(02)00247-7, 2003.

Borrelli, P., Märker, M., and SchüttModelling, B.: Modelling PostTree-Harvesting Soil Erosion and Sediment Deposition Potential in the Turano River Basin (Italian Central Apennine), Land Degrad. Dev., 26, 356-366, https://doi.org/10.1002/ldr.2214, 2015. 
Cerdan, O., Le Bissonnais, Y., Govers, G., Lecomte, V., van Oost, K., Couturier, A., King, C., and Dubreuil, N.: Scale effect on runoff from experimental plots to catchments in agricultural areas in Normandy, J. Hydrology, 299, 4-14, 2008.

Dorren, L. K. A.: A review of rockfall mechanics and modelling approaches, Prog. Phys. Geog., 27, 69-87, 2003.

Fan, J., Oestergaard, K. T., Guyot, A., and Lockington, D. A.: Measuring and modeling rainfall interception losses by a native Banksia woodland and an exotic pine plantation in subtropical coastal Australia, J. Hydrol., 515, 156-165, https://doi.org/10.1016/j.jhydrol.2014.04.066, 2014.

Fiorucci, F., Cardinali, M., Carlà, R., Rossi, M., Mondini, A. C., Santurri, L., Ardizzone, F., and Guzzetti, F.: Seasonal landslide mapping and estimation of landslide mobilization rates using aerial and satellite images, Geomorphology, 129, 59-70, https://doi.org/10.1016/j.geomorph.2011.01.013, 2011.

Fukuyama, T., Onda, Y., Gomi, T., Yamamoto, K., Kondo, N., Miyata, S., Kosugi, K., Mizugaki, S., and Tsubonuma, S.: Quantifying the impact of forest management practice on the runoff of the surface-derived suspended sediment using fallout radionuclides, Hydrol. Process., 24, 596-607, https://doi.org/10.1002/hyp.7554, 2010.

Gabet, E. J.: Sediment transport by dry ravel., J. Geophys. Res., 108, 2049, https://doi.org/10.1029/2001JB001686, 2003.

Goetz, J. N., Guthrie, R. H., and Brenning, A.: Forest harvesting is associated with increased landslide activity during an extreme rainstorm on Vancouver Island, Canada, Nat. Hazards Earth Syst. Sci., 15, 1311-1330, https://doi.org/10.5194/nhess15-1311-2015, 2015.

Gomi, T, Sidle, R. C., Miyata, S., Kosugi, K., and Onda, Y.: Dynamic runoff connectivity of overland flow on steep forested hillslopes: scale effects and runoff transfer, Water Resour. Res., 44, W08411, https://doi.org/10.1029/2007WR005894, 2008.

Gray, A. N., Spies, T. A., and Easter, M. J.: Microclimatic and soil moisture responses to gap formation in coastal Douglas-fir forests, Can. J. For. Res., 32, 332-343, https://doi.org/10.1139/x01-200, 2002.

Haas, F., Heckmann, T., Wichmann, V., and Becht, M.: Runout analysis of a large rockfall in the Dolomites/Italian Alps using LIDAR derived particle sizes and shapes, Earth Surf. Process. Landf., 37, 1444-1445, https://doi.org/10.1002/esp.3295, 2012.

Harris, C., Kern-Luetschg, M., Murton, J., Font, M., Davies, M., and Smith F.: Solifluction processes on permafrost and non-permafrost slopes: results of a large-scale laboratory simulation, Permafrost Periglac., 19, 359-378, https://doi.org/10.1002/ppp.630, 2008a.

Harris, C., Smith, J. S. Davies, M. C. R., and Rea, B.: An investigation of periglacial slope stability in relation to soil properties based on physical modelling in the geotechnical centrifuge, Geomorphology, 93, 437-459, https://doi.org/10.1016/j.geomorph.2007.03.009, 2008b.

Hartanto, H., Prabhu, R., Widayat, A. S. E., and Asdak, C.: Factors affecting runoff and soil erosion: Plot-level soil loss monitoring for assessing sustainability of forest management, Forest Ecol. Manag., 180, 361-374, 2003.

Heng, B. C. P., Sander, G. C., Armstrong, A., Quinton, J. N., Chandler, J. H., and Scott, C. F.: Modeling the dynamics of soil erosion and size-selective sediment transport over nonuniform to- pography in flume-scale experiments, Water Resour. Res., 47, W02513, https://doi.org/10.1029/2010WR009375, 2011.

Higashi, A. and Corte, A. E.: Solifluction: a model experiment, Science, 171, 480-482, https://doi.org/10.1126/science.171.3970.480, 1971.

Imaizumi, F. and Sidle, R. C.: Effect of forest harvesting on hydrogeomorphic processes in steep terrain of central Japan, Geomorphology, 169, 109-122, 2012.

Imaizumi, F., Sidle, R. C., Tsuchiya, S., and Ohsaka, O.: Hydrogeomorphic processes in a steep debris flow initiation zone, Geophys. Res. Lett., 33, L10404, https://doi.org/10.1029/2006GL026250, 2006.

Imaizumi, F., Sidle, R. C., and Kamei, R.: Effects of forest harvesting on the occurrence of landslides and debris flows in steep terrain of central Japan, Earth Surf. Process. Landf., 33, 827-840, 2008.

Imaizumi, F., Hattanji, T., and Hayakawa, Y. S.: Channel initiation by surface and subsurface flows in a steep catchment of the Akaishi Mountains, Japan, Geomorphology, 115, 32-42, https://doi.org/10.1016/j.geomorph.2009.09.026, 2010.

Imaizumi, F., Sidle, R. C., Togari-Ohta, A., and Shimamura, M.: Temporal and spatial variation of infilling processes in a landslide scar in a steep mountainous region, Japan, Earth Surf. Process. Landf., 40, 642-653, 2015.

Imaizumi, F., Suzuki, O., and Togari-Ohta, A.: Seasonal changes in the sediment flux on steep hillslopes in a humid diurnal frost environment, Earth Surf. Process. Landf., 42, 389-398, 2017.

Kirchner, J. W., Finkel, R. C., Riebe, C. S., Granger, D. E., Clayton, J. L., King, J. G., and Megahan, W. F.: Mountain erosion over $10 \mathrm{yr}, 10$ k.y., and 10 m.y. time scales, Geology, 29, 591594, 2011.

Kværn $\varnothing$, S. H. and Øygarden, L.: The influence of freezethaw cycles and soil moisture on aggregate stability of three soils in Norway, Catena, 67, 175-182, https://doi.org/10.1016/j.catena.2006.03.011, 2006.

Lamb, M. P., Scheingross, J. S., Amidon, W. H., Swanson, E., and Limaye, A.: A Model for Fire-Induced Sediment Yield by Dry Ravel in Steep Landscapes, J. Geophys. Res., 116, F03006, https://doi.org/10.1029/2010JF001878, 2011.

Liu, W., Luo, Q., Lu, H., Wu, J., and Duan, W.: The effect of litter layer on controlling surface runoff and erosion in rubber plantations on tropical mountain slopes, SW China, Catena, 149, 167175, https://doi.org/10.1016/j.catena.2016.09.013, 2017.

Matsuoka, N.: Modelling frost creep rates in an alpine environment, Permafrost Periglac. 9, 397-409, https://doi.org/10.1002/(SICI)10991530(199810/12)9:43.0.CO;2-Q, 1998.

Matsuoka, N.: Solifluction rates, processes and landforms: a global review, Earth-Sci. Rev., 55, 107-134, https://doi.org/10.1016/S0012-8252(01)00057-5, 2001.

McCool, D. K., Dun, S., Wu, J. Q., Elliot, W. J., and Brooks, E. S.: Seasonal change of WEPP erodibility parameters for two fallow plots on a palouse silt loam, Trans. Am. Soc. Agric. Biol. Eng., 56, 711-718, 2013.

Meentemeyer, V. and Zippin, J.: Soil moisture and texture controls of selected parmafrosts of needle ice growth, Earth Surf. Process. Landf., 6, 113-125, 1981.

Miyata, S., Kosugi, K., Gomi, T., and Mizuyama, T.: Effects of forest floor coverage on overland flow and soil erosion on hillslopes 
in Japanese cypress plantation forests, Water Resour. Res., 45, W06402, https://doi.org/10.1029/2008WR007270, 2009.

Moreno-de las Heras, M., Nicolau, J. M., Merino-Martín, L., and Wilcox, B. P.: Plot-scale effects on runoff and erosion along a slope degradation gradient, Water Resour. Res., 46, W04503, https://doi.org/10.1029/2009WR007875, 2010.

Nanko, K., Giambelluca, T. W., Sutherland, R. A., Mudd, R. G., Nullet, M. A., and Ziegler, A. D.: Erosion Potential under Miconia calvescens Stands on the Island of Hawaiì, Land Degrad. Dev. 26, 218-226, https://doi.org/10.1002/ldr.2200, 2015.

Ueno, K., Rui, D., Nakamura, D., Ito, Y., and Yamashita, S.: Behavior of vegetation protection slopes during freezing and thawing, Soils Found., 5, 413-424, 2010 (in Japanese, with English abstract).

Ueno, K., Kurobe, K., Imaizumi, F., and Nishii, R.: Effects of deforestation and weather on diurnal frost heave processes on the steep mountain slopes in south central Japan, Earth Surf. Process. Landf., 40, 2013-2025, https://doi.org/10.1002/esp.3776, 2015.

Regüés, D. and Gallart, F.: Seasonal patterns of runoff and erosion responses to simulated rainfall in a badland area in Mediterranean mountain conditions (Vallcebre, Southeastern Pyrenees), Earth Surf. Process. Landf., 29, 755-767, 2004.

Roberts, R. G. and Church, M.: The sediment budget in severely disturbed watersheds, Queen Charlotte Ranges, British Columbia, Can. J. Forest Res., 16, 1092-1106, https://doi.org/10.1139/x86189, 1986.

Roering, J. J., Perron, J. T., and Kirchner, J. W.: Functional relationships between denudation and hillslope form and relief, Earth Planet Sci. Lett., 264, 345-258, https://doi.org/10.1016/j.eps1.2007.09.035, 2007.
Sidle, R. C. and Ochiai, H.: Landslides: Processes, Prediction, and Land Use, American Geophysical Union Water Resources Monograph 18, American Geophysical Union, Washington, DC, 2006.

Sidle, R. C., Gomi, T., Usuga, J. C. L., and Jarihani, B.: Hydrogeomorphic processes and scaling issues in the continuum from soil pedons to catchments, Earth-Sci. Rev., 175, 75-96, https://doi.org/10.1016/j.earscirev.2017.10.010, 2017.

Verity, G. E. and Anderson, D. W.: Soil eroson effects on soil quality and yield, Can. J. Soil Sci. 70, 471-484, https://doi.org/10.4141/cjss90-046, 1990.

Wainwright, J., Parson, A. J., and Abrahams, A. D.: Plotscale studies of vegetation, overland flow and erosion interactions: case studies from Arizona and New Mexico, Hydrol. Process., 14, 2921-2943, https://doi.org/10.1002/10991085(200011/12)14:16/17<2921::AID-HYP127>3.0.CO;2-7, 2000.

Xiao, Q., McPherson, E. G., Ustin, S. L., Grismer, M. E., and Simpson, J. R.: Winter rainfall interception by two mature open-grown trees in Davis, California, Hydrol. Process., 14, 763-84, https://doi.org/10.1002/(SICI)10991085(200003)14:4<763::AID-HYP971>3.0.CO;2-7, 2000.

Zhao, L., Wu, J., Zhang, Q., and Wu, F.: Runoff, erosion and sediment particle size from smooth and rough soil surfaces under steady rainfall-runoff conditions, Acta. Agr. Scand. B.-S. P., 64, 623-632, https://doi.org/10.1080/09064710.2014.949297, 2014. 